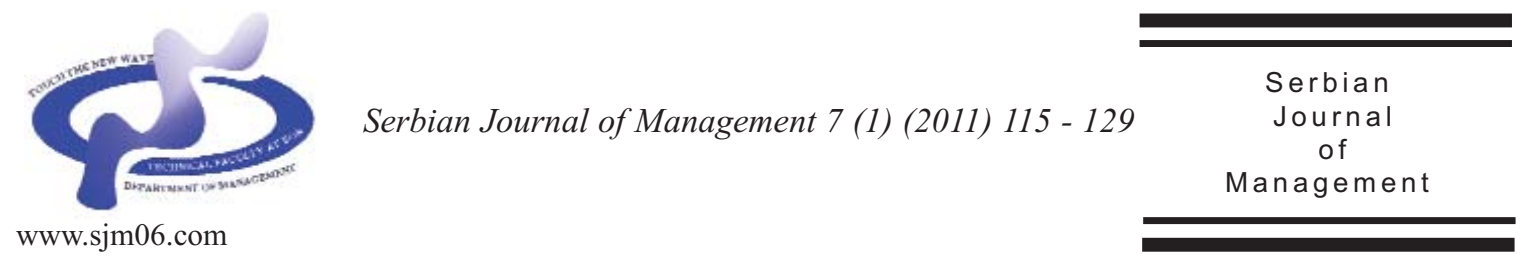

\title{
PERFORMANCE OF HUMAN RESOURCE MANAGEMENT IN AN INTERNATIONALLY OPERATING COMPANY
}

\author{
Ladislav Mura \\ J. Selye University in Komárno, Faculty of Economics, Bratislavská 3322, \\ 94501 Komárno, Slovakia
}

(Received 5 June 2011; accepted 12 September 2011)

\begin{abstract}
In our days, society is greatly influenced and altered by the process of internationalization and globalization. Globalization refers to a whole set of changes, not to one single dimensional change. The process of internationalization puts a special and high importance on the work of human resources managers. In order to remain successful and competitive in the international business environment, companies have to pay close attention to cultural factors. These may considerably differ among workers in multinational companies. We are taking a careful look at human resource management in this new age, and especially at the impact of globalization and internationalization. Our case study is built on the company MOL, specifically on some of the activities it develops in the field of human resource management: training programmes, personnel motivation, career development. We highlight some of the critical aspects of human resources management at MOL, and see what lessons are being learned and what conclusions we can draw.
\end{abstract}

Keywords: Human resources management and development, internationalization, globalization, business company, new employee

\section{INTRODUCTION}

In our days society is influenced and altered by the process of globalization. The economic market place is certainly one of the driving agencies of intensifying globalization, but globalization is not primarily economic in and of itself.
Globalization refers to a set of changes, not a single dimensional change. Many of these changes are social, cultural and political, rather than purely economic, and one of the main drivers in addition to the global marketplace is something partly separable from it, this is the communications revolution. (Beamish et al., 2003;

* Corresponding author: ladislav.mura@gmail.com

DOI: $10.5937 / \mathrm{sjm} 1201115 \mathrm{M}$ 
116

Zadražilová, 2004)

Everywhere we can see the interconnection of national economies and the internationalization of economic processes. In a turbulent changing business environment only those companies that understand the current trends in the global economy are able to survive, develop and prosper. Therefore, the issue of internationalization for most companies acquires more and more importance and the process of internationalization offers the possibilities for survival in this increasingly competitive environment. (Mura \& Gašparíková, 2010; Ebiringa, 2011)

Internationalization helps in creating a new social and cultural model of fast changing Europe enabling everybody to live in culturally diversified societies. It has also become an integral part of educational and scientific activities which promote acquiring new knowledge, study and special experience and, in many cases it helps improve mastering foreign languages(Malá, 2009)

Globalization to me is about a transformation of our basic institutions. It is not just dominated by economic forces, it is much more closely connected with communication. It affects the state, it affects nations, it affects our personal lives. Moreover, globalization is not just about 'out there' phenomena, it is not just about the big systems, it is not just about the global market place, it is not just about processes affecting states. It is an "in here" phenomenon too. Our lives, our personalities, our identities, our emotions, our relationships with other people - these are being reshaped by globalizing processes, because globalization invades local culture.(Runaway World, 2011)

Globalization is a process of increasing interconnectedness of individuals, groups, companies and countries. The technological, economic and political changes which have brought people closer together have also generated serious concerns over the terms of that integration. These concerns have been generated by the realization that while globalization has led to benefits for some, it has not led to benefits for all. The benefits appear to have gone to those who already have the most, while many of the poorest have failed to benefit fully and some have even been made poorer. (Blake, 1999)

\section{MATERIAL AND METHODS}

The purpose of this study is to analyze the theoretical and practical issues and performance of human resource management in chosen company. Our case study is built on the company MOL, specifically on some of the activities it develops in the field of human resource management: to describe the role of human resource management, training programmes, personnel motivation, career development. Accent is placed on selected factors, some of the critical aspects of human resources management at MOL, and see what lessons are being learned and what conclusions we can draw.

The main used method of primary survey was the questionnaire method and technique of driven interview with contacted human resource managers. Processing of questionnaire took place in one stage. There was a processing of the data obtained after treatment of data base was conducted by an MS Office program Excel. Secondary sources were the scientific papers of conferences, monograph and professional portals on the Internet. We were used the logic - cognition methods as an analysis, synthesis, induction, deduction, too. 
This paper was supported by internal Grant „Internationalization of small and medium enterprises in chosen region" of Dubnica Institute of Technology in Dubnica nad Váhom.

\section{RESULT AND DISCUSSION}

\subsection{MOL - an internationally operating company}

MOL Hungarian Oil and Gas Company is a leading integrated oil and gas group in Central and Eastern Europe and the largest company in Hungary by sales revenues. The core activities of the group include (MOL, 2011):

- exploration and production of crude oil, natural gas and gas products

- refining, transportation, storage and distribution of crude oil products in both retail and wholesale markets

- importation, transportation, storage and wholesale trading of natural gas and other gas products.

MOL is the market leader in each of its core activities in Hungary. Its main objective is to provide superior levels of shareholder return by fully exploiting its market potential, by implementing a dynamic development and expansion strategy and by realizing where possible the potential for further internal efficiency improvements. MOL's shares are listed on the Budapest and Luxembourg Stock Exchanges and traded on London's SEAQ International system. MOL's devoted and highly professional team contributes to achieving this challenging task. Accordingly, it demands devotion and marketable knowledge from all of its employees. MOL expects its staff to do its job to the best of its ability, which MOL rewards with generous remuneration packages. Their expectations are in keeping with their vision which includes excellence, focus and dynamism:

\section{Excellence}

Its staff members are outstanding professionals who make every effort to continually update and broaden their knowledge. Their performance is characterised by consistently high standards.

Focus

With their work company employees seek to contribute to achieving the overall strategic and business objectives of the company.

\section{Dynamism}

Staff members are open to innovation and take a flexible attitude to change. MOL works effectively in a multicultural environment and takesthe advantage of the potential multiculturalism has to offer. They do their job independently and responsibly, but being excellent team players, they are also willing to co-operate with others.

\subsection{Human resource management inselected company}

As a global player MOL hasa long list of advantages to offer their employees. What MOL can offer employees:

- challenging work

- modern working conditions

- comprehensive professional career opportunities

- competitive salary

- international working environment

- project jobs.

MOL believes, there is an opportunity in every challenge - it is this challenge which MOL has to offer." To make the integration of the new employee easier there must be 


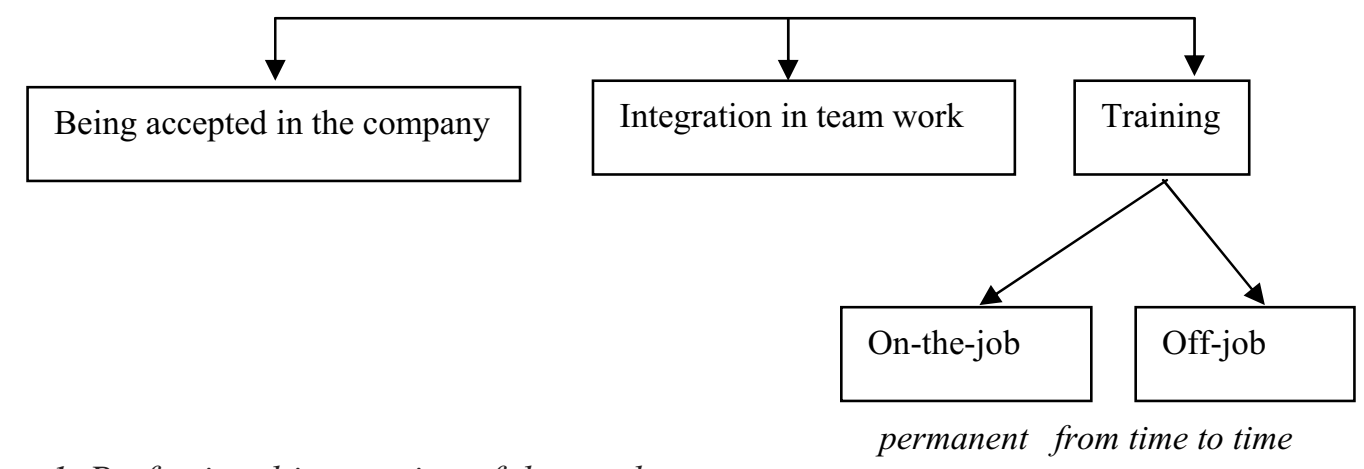

Figure 1. Professional integration of the employees

fulfilled three conditions (see Figure 1): distrust.

- A clear definition of labour condition, Professional integration realizes tight

- Helping the new employees to adapt cooperation between managers, the human themselves to the work tasks,

- Make him/her trust the company. resource department and the supervisors as

The company has established a professional integration programme which has as its main purpose to support the new employees in adapting to the new working (labour) conditions. They are given information in order to eliminate tension and can be seen in Figure 2.

The integration process of the new employee is complex and needs time, integration depending on several factors which refer to motivation, personal and group behavior, relationships, social and family situations, and organizational culture.

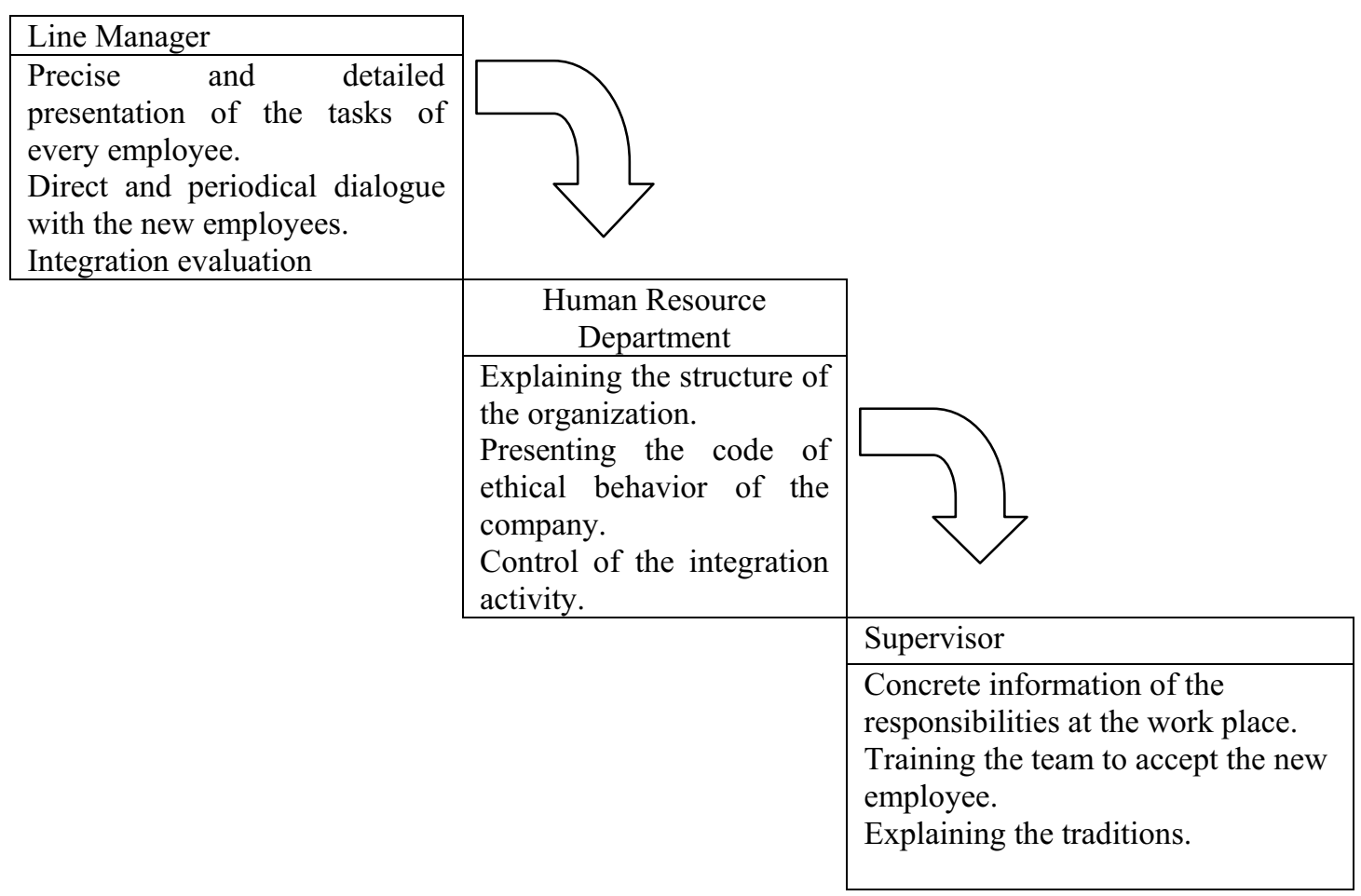

Figure 2. Human resource integration process 


\subsection{Training strategy and programmes}

The company must also help the new employee to identify himself with the company. MOL understands what is its role concerning the development of its employees and the result is a set of complex training programmes. Training programmes must be part of corporate education (Š́bertová, 2007).

Training programmes include the following type of activities:

Sales conferences. Participants at this kind of programme are: senior management, line management, managers from every gas station. In this training programme every department manager can present to the other managers the objectives for the following period, the results achieved until that moment, the actions that will take place, and the resource that will be needed. Managers from the gas stations have the opportunity to communicate to senior management their problems and to find ways to solve them.

Team building. In this training programme the participants are the employee from the gas stations and it is an opportunity for them to build strong teams based on trust. Key words that can define the final results of the team building programme are:

$$
\begin{array}{ll}
- & \text { Knowledge } \\
- & \text { Flexibility } \\
- & \text { Creativity } \\
- & \text { Responsibility } \\
- & \text { Enthusiasm } \\
- & \text { Professionalism } \\
- & \text { Results }
\end{array}
$$

The results of this programme are: a real team at every gas station, better division of the tasks for the members of team, efficient working environment.

Sales team management. Its purpose is to introduce the necessary practices in the sales department and the development of abilities necessary to the sales managers.

Sales oriented training. This is an annual training programme in active sales realized in collaboration with two specialized companies. The results of the programme are in a new programme called "Train the Trainer ". During this programme 2-3 employees from each gas station are trained. These employees will share their knowledge with the others. This type of programme is very popular in the United States and other developed countries. The programme develops basic abilities which are necessary in the training process.

The basic principles of the active sales at MOL are the quality of the products and the satisfaction of the customer. The two principles are correlated and have an influence on each other.

This type of training programme transforms the managers of every gas station into commercial trainers whose role is:

- To be a sponsor because he supports and motivates his colleagues in order to achieve similar performance.

Table 1. Passive and active sale

\begin{tabular}{|l|l|}
\hline \multicolumn{1}{|c|}{$\boldsymbol{P A S S I V E \boldsymbol { S A L E }}$} & \multicolumn{1}{|c|}{$\boldsymbol{A C T I V E} \boldsymbol{S A L E}$} \\
\hline $\begin{array}{l}\text { The client enters the } \\
\text { gas station. He leaves } \\
\text { without being } \\
\text { influenced to come } \\
\text { back. }\end{array}$ & $\begin{array}{l}\text { The client is } \\
\text { welcomed by the staff } \\
\text { of the gas station in a } \\
\text { friendly way. }\end{array}$ \\
\hline & $\begin{array}{l}\text { The client finds out } \\
\text { what the advantages of } \\
\text { the frequent use of } \\
\text { high quality gas are. }\end{array}$ \\
\hline & $\begin{array}{l}\text { He receives advice in } \\
\text { order to buy other } \\
\text { products that his car } \\
\text { needs. }\end{array}$ \\
\hline & $\begin{array}{l}\text { He receives } \\
\text { recommendations }\end{array}$ \\
\hline
\end{tabular}




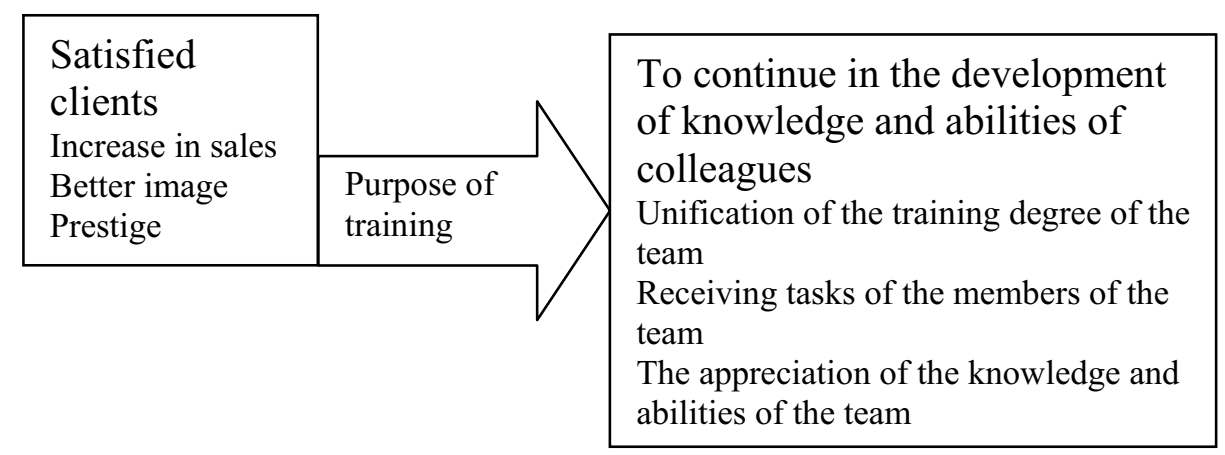

Figure 3. Purpose and results of the training programs

- $\quad$ To be a trainer because he teaches his colleagues, he offers them supplementary explanations when needed.

- To be a training partner because he makes demonstrations, coordinates practical exercises.

- To give feed-back and evaluate the results of the trained colleagues.

- To solve problems, give advice, support the finding of solutions. (see Figure 3)

The role of the trainer after the training program is to communicate and to transmit the achieved knowledge and at the end to give feed-back in order to obtain better performance of the personnel working in gas stations.(Nagyováet al., 2005)

The purpose of the feed-back:

- Objective appreciations of the colleagues ' performance and their solutions,

\begin{tabular}{|l|}
\hline \multicolumn{1}{|c|}{ Situation } \\
\hline $\begin{array}{l}\text { The operator does } \\
\text { not recommend the } \\
\text { client when filling } \\
\text { gas to wash the } \\
\text { windscreen }\end{array}$ \\
\cline { 2 - 2 }
\end{tabular}

- Make the colleagues have self confidence and maintain a decent level of professional self appreciation,

- $\quad$ Finding the fields which need change and development,

- Make the colleagues act as a team: use their ideas and proposals for better performance.

A proper feed-back is individual, concrete, prompt, focuses on the solution not on the problem. The advantage of a proper feed-back has an impact on the atmosphere among the employees and the way that the mistakes will be perceived. So the mistakes will not be seen as a failure, but as a possibility to develop. Using a feed-back you can determine what is good, what must be changed and what are the steps that must be made to make the change as it is in the example from the Figure 4.

\begin{tabular}{|l|l|}
\hline $\begin{array}{l}\text { What is } \\
\text { good }\end{array}$ & $\begin{array}{l}\text { You are very polite with } \\
\text { the customers } \\
\text { What } \\
\text { to be } \\
\text { changed }\end{array}$ \\
Next step & $\begin{array}{l}\text { [.. When filling gas you } \\
\text { must recommend the } \\
\text { washing of the windscreen } \\
\text {... Before finishing the } \\
\text { gas fill ask every client: } \\
\text { would you like me to wash } \\
\text { the windscreen? }\end{array}$ \\
\hline
\end{tabular}

Figure 4. Feed-back 
Table 2. Advantages of solving problems using the feed-back

\begin{tabular}{|l|l|l|}
\hline \multicolumn{1}{|c|}{ CRITICAL } & $\Leftrightarrow$ & \multicolumn{1}{|c|}{ FEED-BACK } \\
\hline It is personal & $\Leftrightarrow$ & $\begin{array}{l}\text { Describes the } \\
\text { behavior }\end{array}$ \\
\hline Generalizes & $\Leftrightarrow$ & $\begin{array}{l}\text { Based on a } \\
\text { concrete fact }\end{array}$ \\
\hline $\begin{array}{l}\text { Focuses on the } \\
\text { problem }\end{array}$ & $\Leftrightarrow$ & $\begin{array}{l}\text { Focuses on the } \\
\text { solutions }\end{array}$ \\
\hline Blames & $\Leftrightarrow$ & $\begin{array}{l}\text { Instigates } \\
\text { changes }\end{array}$ \\
\hline Based on opinions & $\Leftrightarrow$ & Based on facts \\
\hline Qualifies & $\Leftrightarrow$ & It is objective \\
\hline
\end{tabular}

This way there will be solved a problem in an efficient way than it was solved in a traditional way by criticism before the training programme (see Table 2).

The way in which the trainer transmits the information depends on the employee's development level (see Table 3).

The one who will transmit knowledge gained during training programmes to his colleagues can face some problems which are dependent or independent on him. Aware of the obstacles which stand between transmitting knowledge to colleagues, the company which had implemented the training programme identified these obstacles and looked for solutions.

\subsection{Some critical aspects}

In the Table 4, there are some obstacles which trainers have to face while transmitting the information to colleagues.

Among the 100 participants in the training program only 25 reported that they had confronted these obstacles, methods presented above were used by them to manage to over come these obstacles.

Although they were presented with some solutions for solving the problems none of the trainer had faced such an obstacle which means that a first step was made: the employees working at the gas station wanted to learn to develop their abilities and so to contribute to obtaining higher performance.

Among the 100 participants 43 had faced this obstacle but each of them found solutions for solving them.

At the end of the training programme each participant is tested to see the level of the knowledge gained in order to train the other colleagues. This programme also aims at

\section{Table 3. Levels of development}

\begin{tabular}{|c|c|}
\hline Development level & $\begin{array}{c}\text { Way to transmit } \\
\text { knowledge }\end{array}$ \\
\hline Apprentice $\Rightarrow$ & Guidance \\
\hline & $\begin{array}{l}\text { Detailed instructions in } \\
\text { writing } \\
\text { Detailed precise } \\
\text { explanations } \\
\text { Direct and systematic } \\
\text { supervision, feed-back } \\
\text { Demonstrations of the } \\
\text { existing solutions and } \\
\text { their assimilation } \\
\text { "you do so" }\end{array}$ \\
\hline \multirow{2}{*}{ Help $\Rightarrow$} & Develop \\
\hline & $\begin{array}{l}\text { Exercise } \\
\text { Systematic feed-back, } \\
\text { corrections } \\
\text { Propose solutions for } \\
\text { solving } \\
\text { "how you could do it } \\
\text { better". }\end{array}$ \\
\hline \multirow[t]{2}{*}{ Specialist $\Rightarrow$} & Support \\
\hline & $\begin{array}{l}\text { Solving problems } \\
\text { Common thinking } \\
\text { "what we should do" }\end{array}$ \\
\hline \multirow[t]{2}{*}{ Master $\Rightarrow$} & Coaching \\
\hline & $\begin{array}{l}\text { Coaching for trainer } \\
\text { role } \\
\text { "how you could } \\
\text { explain to others"، }\end{array}$ \\
\hline
\end{tabular}

improving the methods of learning. If the results are not satisfactory the training programme can be extended in order to clarify the weakness of some of the participants.

Training programmes are a way in which MOL tries to achieve its objectives: increasing sales, client's loyalty, network extension. The subjects of this programme 
Table 4. Some obstacles and solution

\begin{tabular}{|l|l|}
\hline \multicolumn{1}{|c|}{ Obstacle } & \multicolumn{1}{c|}{ Solution } \\
\hline $\begin{array}{l}\text { 1. The fear of a colleague's reaction at his role } \\
\text { and his person. }\end{array}$ & $\begin{array}{l}\text { Open communication for collaboration } \\
\text { Demonstration of the purpose and the advantages } \\
\text { of training program } \\
\text { Exact definition of trainer's role } \\
\text { Request ideas and proposals from colleagues } \\
\text { Training colleagues with high qualification and } \\
\text { strong motivation during the training programme }\end{array}$ \\
\hline 3. Tiredness & $\begin{array}{l}\text { Ask for manager support } \\
\text { Equitable distribution of tasks }\end{array}$ \\
\hline 4. Low transfer of learning & $\begin{array}{l}\text { Clarify the problems } \\
\text { Ask for proposals } \\
\text { Explain the purpose of the training } \\
\text { Exact definition of the trainer's role } \\
\text { Underline the advantages of the trainer }\end{array}$ \\
\hline & $\begin{array}{l}\text { Detailed explications } \\
\text { Frequent demonstrations } \\
\text { Systematic evaluation } \\
\text { Simple step in the training process }\end{array}$ \\
\hline
\end{tabular}

are the employees whose purposes must meet the ones of the organization and this is possible only by motivating them. Employee's motivation has an influence on the quality and the quantity of their work.

\section{MOTIVATION AND CARRER DEVELOPMENT}

In our days motivating people can offer a real competitive advantage. So each company tries to do the best in this field and to offer a real package of opportunities (Nagyová et al., 2005).

Establishing the methods of the staff motivations is a process which has the following steps:

- Necessity of employees' motivation

- Understanding the nature of motivation

- Clarify team motivation

- Factors which determine performance.
Payment is important but it is not independent from the non-financial motivation which makes the company more attractive on the market and more stable in what concerns the employees.

MOL made the two aspects of motivation to coexist and to develop. The financial package contains: the basic salary, annual bonus if the objectives were achieved properly, project bonuses, car, mobile phone, paid trips, Christmas bonuses.

Non-financial motivational elements:

- Organizational structure which permits a precise definition of the responsibilities

- Investment in professional training and managerial development

- Develop the coaching process

- Implementing the individual plan of development.

A nice working environment, flexibility, an atmosphere of trust are some of the necessary ingredients next to the payment package that are a key to the success of a 
company which must be competitive and efficient.

\subsection{Career Development}

MOL is one of the companies which offers their employees professional success. One can find here employees with great experience but also young people who want to be noticed.

The following aspects make MOLan attractive company:

- A favorable environment which makes the employees be loyal to the company

- A system that permits a correct evaluation of the employees

- The possibility to move from one department to another, from one region to another

- An effective communication system

- An informational system of the employees about new projects of the company and the efforts needed to carry out these projects

- A career policy.

What must an employee do to be promoted:

- $\quad$ To finish the work in time

- $\quad$ To finish the work properly

- To present a favorable image to clients and partners

- To defend the company when needed

- To use a certain language and to be persuasive

- To admit his mistakes, and to correct his actions

- To appreciate and admit his coworkers achievements.

An employee must be:

- Well informed and eager to be informed in his domain and outside of it

- Always present at social activities
- $\quad$ Polite and kind with colleagues and clients

MOL is a multinational company, one of the most important in Central Europe. That is why its employees have lots of opportunities.

Strong points of the company:

- They have gas stations all over the country and they are still developing, offering many job opportunities and possibilities to be promoted

- Competitive work environment

- Flexible, dynamic company which shows great attention to changes tries to adapt and to satisfy their clients', suppliers' and employees' needs.

A difficult problem for the company is the employee's migration. That is why the company offers the following opportunities for its employees:

- professional training for all the employees, the company makes serious investments in training programmes

- developing motivational programmes to gain the loyalty of the staff

- encouraging internal promotion.

MOL's competitors have a rapid rate of developing, so the company must face them in order to have and keep its best employees.

The purpose of MOL company is to become an important player on the market and that is why it needs qualified, motivated and loyal employees. This will happen only if the company will be interested in finding out what its employees want, what they expect to be offered and if the company will specify clearly what it wants from its employees: "MOL is a company to work for and to work with".

\section{LESSONS LEARNED}

Smartee with the support from IRSOP Market Research have made a study at the 
end of 2008 in order to observe the actual stage of the human resource management in companies which interact in the market. (see on Figure 5 and Figure 6)

From this study we can draw the following conclusions:

- $\quad 69 \%$ of human resources managers consider that the human resources development is very important

- training and employees' development is a priority in multinational companies

- $\quad$ small firms are interested in training employees but because of the lack of material resources they prefer on-the-job training

- the planification of human resources development is on short term, not long term as it should be

- big scale companies are more interested in buying computer programmes in order to make the activities of the human resources department more efficient.

The SME companies which interact in the Hungarian market must rely more on-the-job training. On-the-job training is usually defined as informal learning and hides the learning process as "learning by doing", traditional methods of learning in class must be replaced by other concepts although some people are convinced that the traditional methods are still useful. Learning content must be based on concrete needs of learning from the organization.

On-the-job training is becoming more and more useful as we can conclude from Figure 7. Human resources departments are present in more companies than in the past.

Some organizations need to change their attitudes and their work practices. The role of senior and line managers gains importance, they become moderators. We need democratic management not autocratic. The real environment asks that the managers are trainers and teachers.

Another problem is the selection of training firms because the organization doesnot show a lot of interest in this area. Human contact and recommendations are often used as a source of information because there aren't any systems of evaluation of training programs. The figure

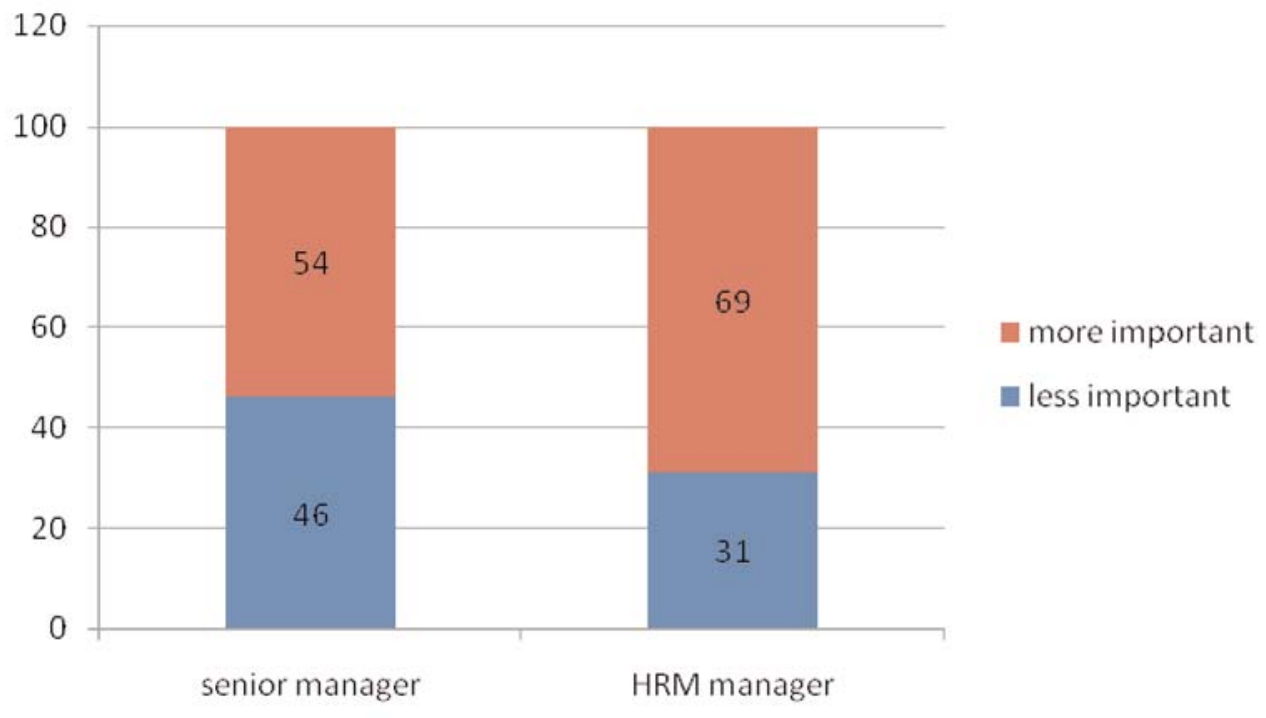

Figure 5. The importance of training in organizations 


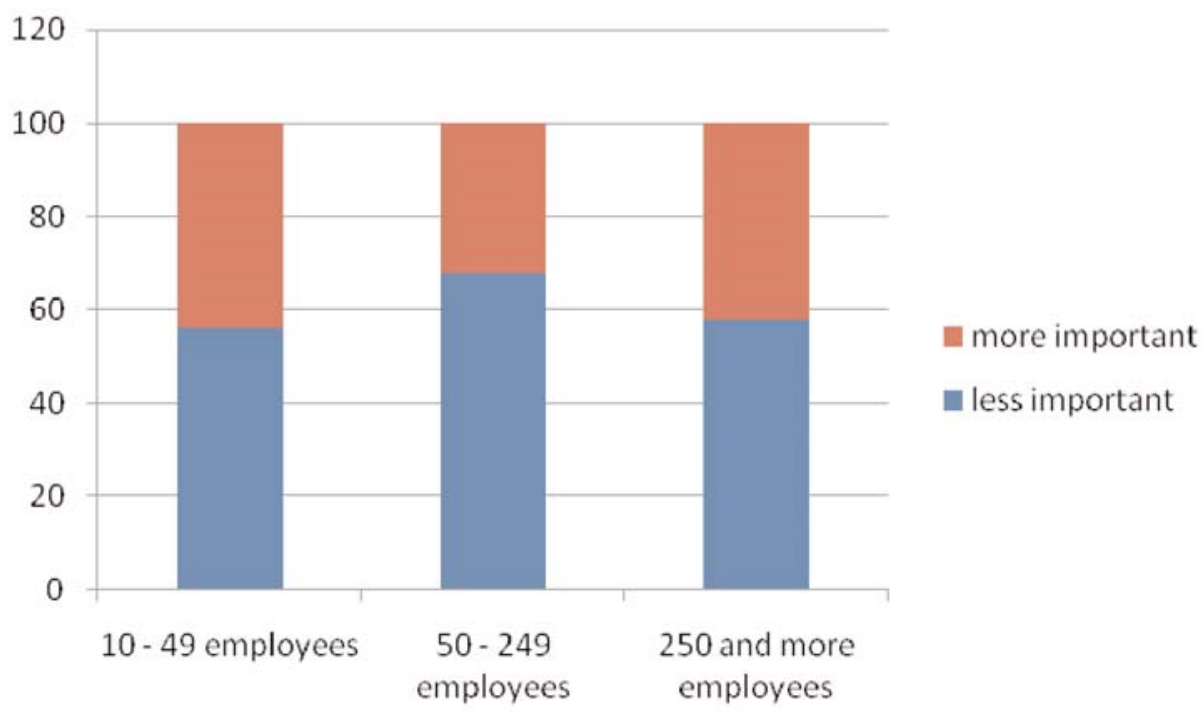

Figure 6. The importance of training in organizations according to SME segmentation

number shows that when selecting a course one must follow three steps:

- consulting the personal contacts and obtaining recommendations together with studying the received offers

- consulting the internet for more information

- accepting a meeting with the training programme's supplier in order to receive the needed information.

The main criteria for organizations in choosing training programmes isthe price (see Figure 8), because the budget for training activities is limited. The quality of training courses comes on the second place in the criteria hierarchy in selecting the training firms (see Figure 9), followed by the personnel needs and underlying the care for

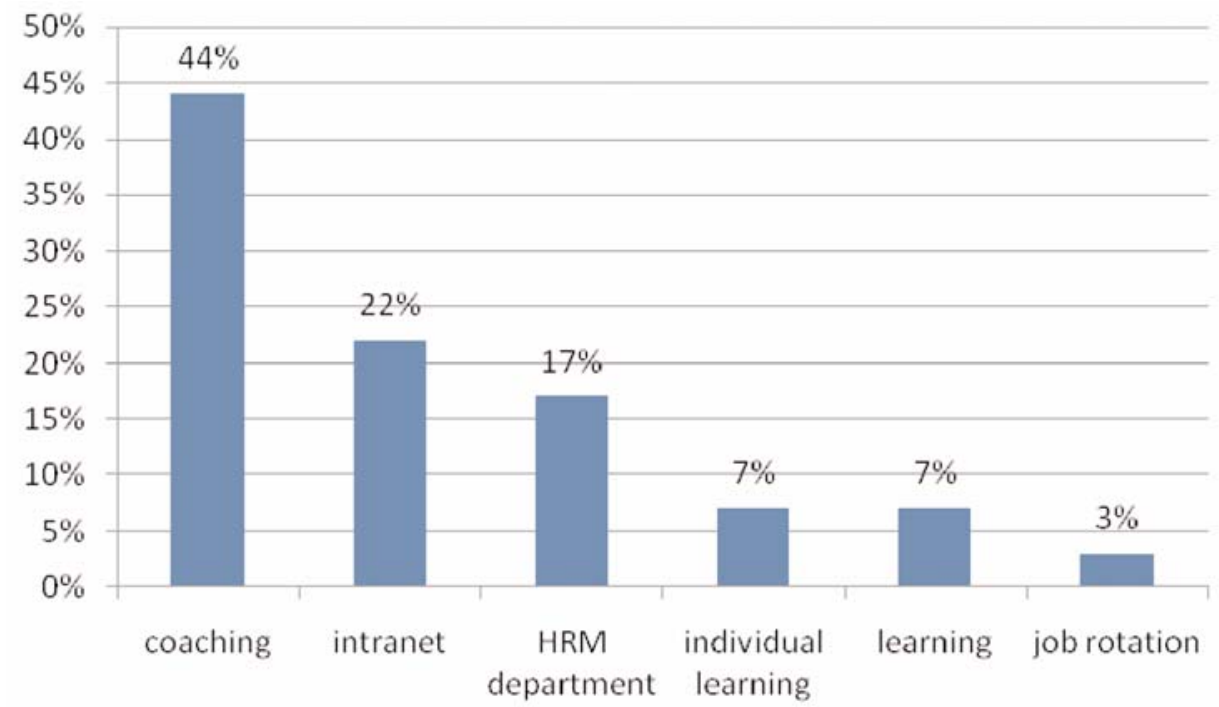

Figure 7. The importance of training in organizations according to SME segmentation 


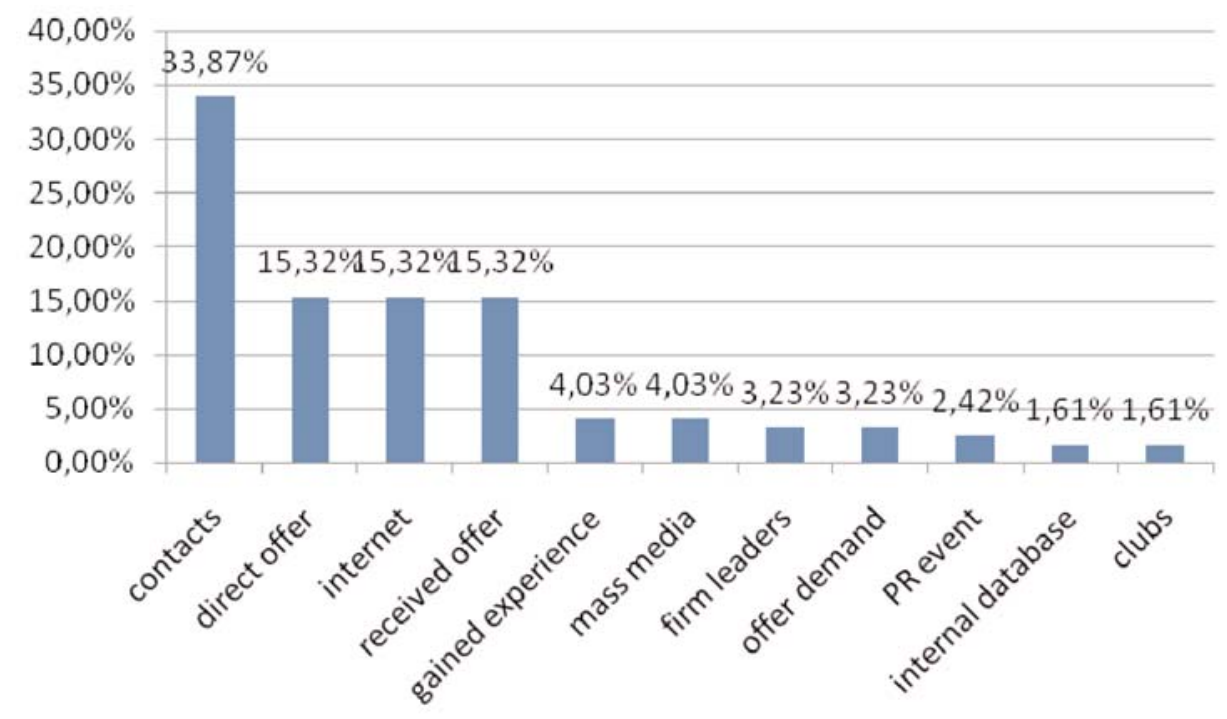

Figure 8. Sources of information for training programmes

human resources development.

Most of the companies prefer to work with the suppliers of training programmes because it is very difficult and expensive to contact foreign firms. There are many training firms in Hungarybut only $40 \%$ of the beneficiary company appreciates quality of their programmes as satisfactory and $20 \%$ as good. This happens because most of the firms donot offer service post selling (final participants evaluations, training programme monitoring) and service before selling (training need evaluation, realized demonstrative courses).30\% of the beneficiary company evaluates the quality of their programmes as slight and $10 \%$ as variable (see Figure 10).

One weakness of Hungarian organizations is that they do not evaluate the results continuously. To realize a real evaluation

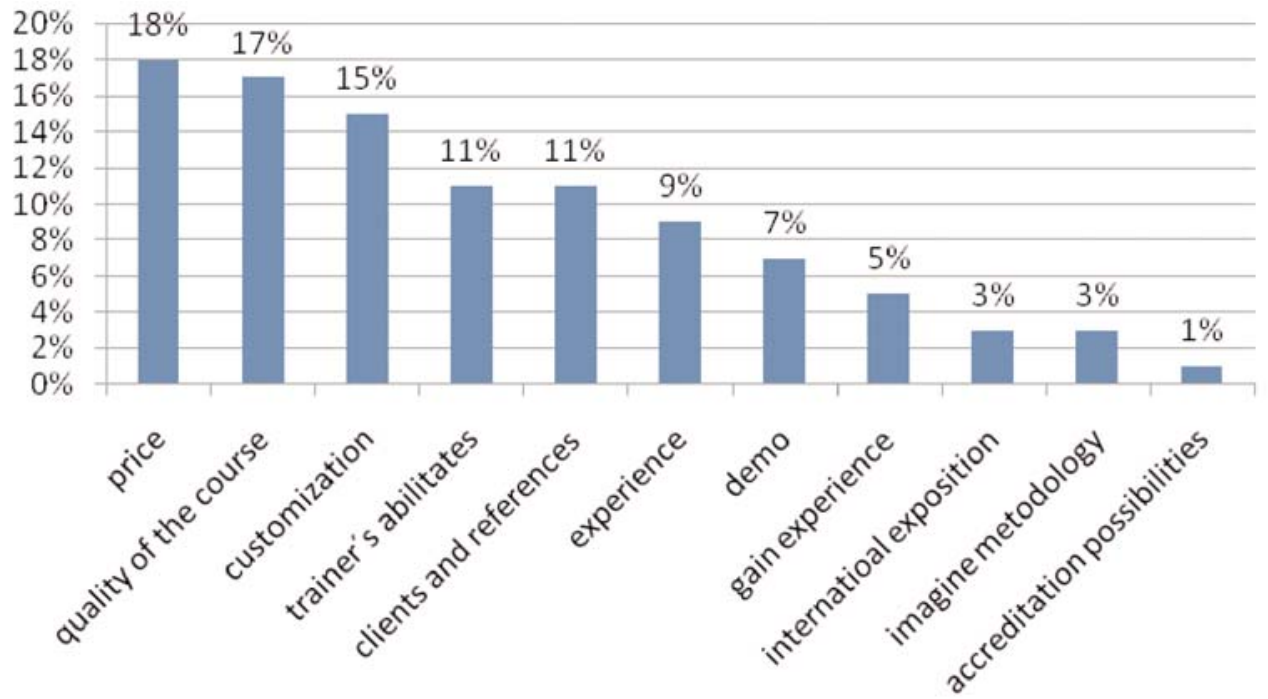

Figure 9. Criteria in selecting the training firms 


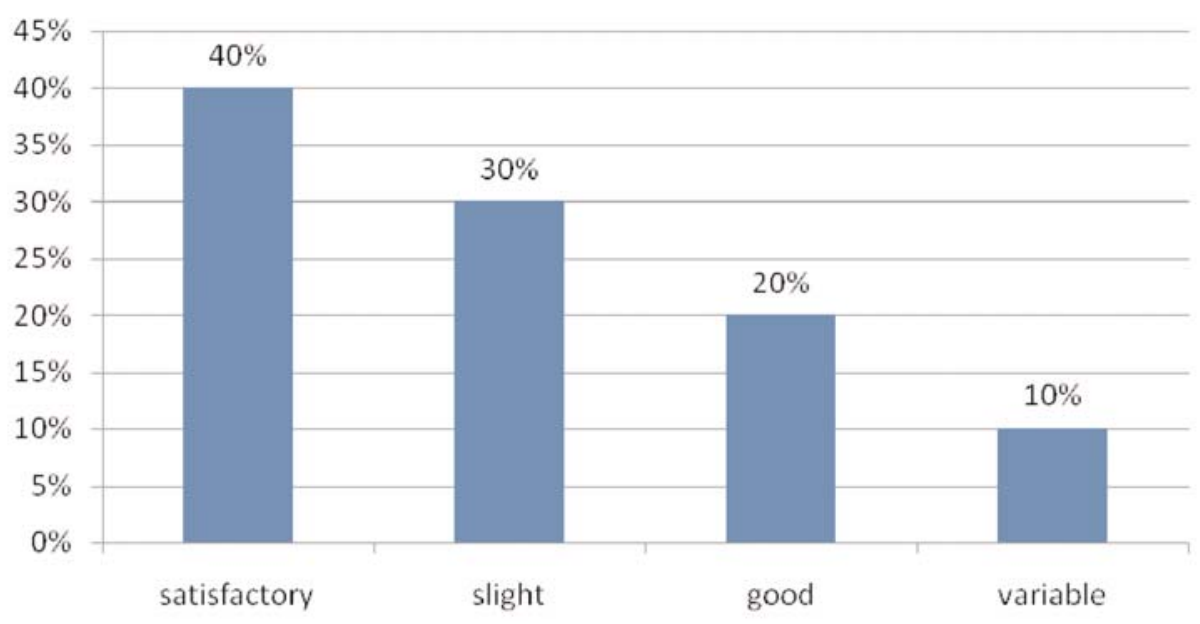

Figure 10. The quality of training firms

firms must establish measurable, clear criteria of evaluation. Organizations must focus on the quality of the criteria also, and be informed on participants' opinions, their problems, their abilities and competences.

Government has an important contribution in the process of human resources development. Government policy must encourage young people and their families to support the educational and professional development. Supported by the European Union, Hungary will succeed in implementing the necessary programmes in order to achieve the international standards of evaluation and the human resources competences certification. The most significant objectives of these programmes are:

- Development of new methods of teaching and learning

- Training of teachers and trainers for developing innovative methods, using information technology and communications as ways of learning

- New system and practice for stimulating the employers' interest in human rights development

- Development of institutional system in consulting and professional orientation - New form of professional development organizations

- Train the specialists and the experts for evaluating the training programmes

- Encourage investments in people

- Make some studies on the needs of the human resources market

- Stimulating cooperation between organizations in hiring newly graduated unemployed

- Adaptation of training offers to the needs of the labour market.

\section{CONCLUSION}

Human resources development must be a dynamic, flexible process ready to introduce new learning and training methods and techniques.

The whole organization and its structures must be part of this process and the ideal way is to create an environment where people feel comfortable, useful, and ready to fulfill their tasks successfully. Organizations must "take a glance" at the way their employees behave in their families and in their social 
interactions in order to help and understand provocative they are.

their needs.

The purpose of MOL company is to become an important player on the market and that is why it needs qualified, motivated and loyal employees. This will happen only if the company will be interested in finding out what its employees want, what they expect to be offered and if the company will specify clearly what it wants from its employees.

The globalization makes organizations need people who can adapt in any economical, cultural, political, and technical environment. We must invest in human resources development in order to face changes successfully no matter how

\title{
ПЕРФОРМАНСЕ УПРАВЉАҢА ЉУДСКИМ РЕСУРСИМА У ИНТЕРНАЦИОНАЛНОЈ КОМПАНИЈИ
}

\author{
Ladislav Mura \\ J. Selye University in Komárno, Faculty of Economics, Bratislavská 3322, \\ 94501 Komárno, Slovakia
}

\section{Извод}

У данашње време, људско друштво је под великим утицајем интернационализма и глобализације. Глобализација се односи на читав сет промена, а не на једну димензију промене. Процес интернационализације постаља специјалну и високу важност на рад менаџера људских ресурса. У циљу постизања успеха и останка компетенција у окружењу интернационалног пословања, компаније морају придавати велики значај културним факторима. Ово може значајно да се разликује међу случајевима мултинационалних компанија. У ово ново доба, посебна се пажња посвећује менаџменту људских ресурса, и то посебно на утицај глобализације и интернационализације. У овом раду је представљена студија случаја која је формирана за компанију МОЛ, посебно за неке активности које она развија на пољу управљања људским ресурсима: програми тренинга, мотивација запослених, развој каријере. Истичу се неки од критичних аспеката менаџмента људских ресурса у МОЛy, и истиче које се лекције могу научити и који закључци извући.

Кључне речи: Менаџмент и развој људских ресурса, интернационализација, глобализација, пословна компанија, нови запошљени 


\section{References}

Beamish, W. P. (2003). International Management. University of WesternOntario, Canada, University Publishing. p. 626

Blake, H. D. (1999).The Political Environment of Multinational Corporations. Handbook of International Business II.New York. pp. $3-21$.

Ebiringa, O.T. (2011) Optimal business decision system for multinationals: a multifactor analysis of selected manufacturing firms, Serbian Journal of Management, 6(1): 17-26.

Malá, E. (2009). Language and interculturaldimension in the processofinternationalisationofhighereducation. Ianua ad LinguasHominesqueReserata II.Paris. pp. 100 -123 .

Mura, L. - Gašparíková, V. (2010). Penetration of small and medium sized food companies on foreign markets. ActaUniversitatisAgriculturaeetSilviculturae MendelianaeBrunensis.58 (3): 157 - 164.

MOL. (2011)The web side of MOL compay.

http://www.mol.hu/hu/a_molrol/tarsasagunkr ol/

Nagyová, L. et al. (2005).Human resource management Slovac University of Agriculture in Nitra, Slovakia, Published by SUA. p.166

Runaway World:The Reith Lectures $\mathrm{r}$ e $\mathrm{v}$ i $\mathrm{s}$ i $\mathrm{t}$ e $\mathrm{d}$. ( ( $\left.\begin{array}{llll}2 & 0 & 1 & 1\end{array}\right)$. http://www.lse.ac.uk/Depts/global/.../1ReithL ecturesGlobalisation.pdf

Š́bertová, E.(2007) Management, economics and entrepreneurship in highereducation in the Slovak Republic.ScientificPapersof the STU. 3 (1): 13-15.

Zadražilová, D. (2004). International management. Praha, Czech Republic: Grada Publishing. p. 180 